\section{Ulaganja i izvoz u kontekstu konkurentnosti hrvatskih poduzeća ${ }^{1}$}

\section{Investment and export in the context of Croatian companies' competitiveness}

\section{Sažetak}

Ovaj rad prikazuje odnos ulaganja u dugotrajnu imovinu i prihoda od izvoza u razdoblju od 2006. do 2015. godine za tristo najvećih hrvatskih izvoznih poduzeća. Radom se propituje utječu li ulaganja na jednak način na poduzeća koja ostvaruju većinu svojih prihoda od izvoza i na poduzeća koja ostvaruju prihod na domaćem i inozemnom tržištu. Metode deskriptivne i inferencijalne statistike pokazale su kako najviše zastupljenih poduzeća dolazi iz prerađivačke industrije (55\%), a po djelatnostima iz trgovine na veliko (manje od $10 \%$ poduzeća). Dugotrajna imovina najviše je narasla u djelatnostima: poljoprivrede, proizvodnje prehrambenih proizvoda, trgovine na malo, skladištenja, proizvodnje strojne opreme, proizvodnje farmaceutskih proizvoda, prerade drva, te prikupljanja, obrade i zbrinjavanja otpada, dok su negativne promjene uočene u: proizvodnji duhanskih proizvoda i proizvodnji papira i proizvoda od papira. Proizvodnja ostalih nemetalnih mineralnih proizvoda i vodeni prijevoz imaju podjednak promjenjiv i dinamičan obrazac ulaganja. Najveći porast prihoda od izvoza nalazi se u djelatnosti trgovine. Ulaganja u dugotrajnu imovinu povećavaju izvoz poduzeća koje nije u potpunosti izvozno orijentirano više nego u potpunosti izvozno orijentiranog poduzeća.

Ključne riječi: ulaganja u dugotrajnu imovinu, izvoz, ulaganja u materijalnu imovinu, konkurentnost,Hrvatska JEL klasifikacija: D25, E22, F19, F20, M16, P45

\section{Abstract}

This paper explores the relationship between investment in fixed assets and export revenues in the period 2006-2015 for 300 largest Croatian exporters. The paper examines whether investments affect differently companies that generate most of their revenues abroad than those that generate revenues in both domestic and foreign markets. Methods of descriptive and inferential statistics showed that the majority of companies come from the manufacturing industry $(55 \%)$, deal with wholesale trade (less than $10 \%$ of companies). The most significant increase in fixed assets is visible in agriculture, food production, retail trade, warehousing, production of hardware, production of pharmaceutical products, wood processing, and collection, treatment and disposal of waste, while negative changes were observed in: production of tobacco products and production of paper and paper products. The production of other non-metallic mineral products and water transport have an equally variable and dynamic pattern of investment. The largest increase in export earnings comes from trade activities.

1 Rad se temelji na diplomskom radu Martine Ferko (rođena Crnogaj), mag.oec., čija je mentorica bila dr.sc. Maja Bašić.

\section{Maja Bašić}

Dr.sc.

Ekonomski fakultet Sveučilišta u Zagrebu

E-mail:mbasic1@net.efzg.hr

\section{Martina Ferko,mag.oec.}

E-mail:martina.crnogaj19@gmail.com

\section{Martina Sopta Corić}

Izv. prof. dr.sc.

Ekonomski fakultet Sveučilišta u Zagrebu E-mail:msopta@efzg.hr

\section{Maja Bašić}

$\mathrm{PhD}$

Faculty of Economics and Business, University of Zagreb

E-mail:mbasic1@net.efzg.hr

\section{Martina Ferko, mag.oec.}

E-mail:martina.crnogaj19@gmail.com

\section{Martina Sopta Corić}

Assoc. prof.

Faculty of Economics and Business,

University of Zagreb

E-mail:msopta@efzg.hr 
Bašić, M., Ferko, M., Sopta Corić, M.

Ulaganja i izvoz u kontekstu konkurentnosti hrvatskih poduzeća

Investments in fixed assets increase exports of a not fully export-oriented company more than a fully export-oriented company.

Keywords: investment, export, fixed asset investment, competitiveness, Croatia

JEL classification: D25, E22, F19, F20, M16, P45

\section{Uvod}

U današnje vrijeme Republika Hrvatska suočava se s problemima koji otežavaju poduzećima ulaganja koja bi vodila većoj učinkovitosti, te posljedično profitabilnosti. Nepovoljna poslovna klima rezultira statusom quo u odnosu na prethodna razdoblja (Svjetski ekonomski forum, 2019.), a nisu je zaobišla ni globalna ekonomska kretanja poput izazova gospodarske krize uzrokovane pandemijom Covid-19, nametanja carina od strane Sjedinjenih Američkih Država prema Europskoj uniji i Kini te Brexit-a. Kako je održivost međunarodnih trgovinskih tokova neophodna za male otvorene ekonomije (Skoko i Zvonko, 2018.), te imajući u vidu da je nacionalni ekonomski sustav sastavljen od mreže učinkovitih pojedinačnih poslovnih sustava (Landika i suradnici, 2017.), reintegracija globalnog tržišta neminovna je usprkos navedenim izazovima, a pridonose joj i predanost razvoju prometne i informacijske i komunikacijske infrastrukture (npr. Belt and Road Inititative, Three Seas Initiative, 17+1, Europski kohezijski fondovi, itd.), te transnacionalne proizvodnje (Grgić i Bilas, 2008.).

Kako je Europska unija najvažnije izvozno tržište hrvatskih poduzeća (Ćudina i suradnici, 2012.), članstvom Republike Hrvatske u Europskoj uniji izvoz hrvatskih poduzeća poboljšao je svoj položaj (konkurentnost), no nije se vratio na razinu ostvarenu prije globalne recesije 2008 godine (Buturac, 2019.). Prerađivačka industrija obuhvaća oko $90 \%$ posto ukupnog izvoza robe (Državni zavod za statistiku, 2020.), čiji se udio očituje i u konkurentnosti hrvatske ekonomije (Basarac i Vučković, 2011.). Dodatnom analizom relativnog položaja uslužnog sektora Republike Hrvatske u Europskoj uniji, rezultati ukazuju na napredak u konkurentnosti hrvatskih poduzeća (Lacković Vincek i suradnici, 2019.). Međutim, prethodna istraživanja pokazala su ispodprosječnu inovacijsku aktivnost hrvatskih poduzeća (Novak,
2020.), koja se očituje u smanjenju, stagnaciji ili malom rastu dugotrajne imovine, a posebice dugotrajne nematerijalne imovine. Stoga, kako bi se ispitalo imaju li hrvatska izvozna poduzeća alate (posebice ulažu li u tehnologiju koja utječu na rast učinkovitosti) kojima poboljšavaju svoju konkurentnost na europskom, ali i svjetskom tržištu, ovaj rad daje prikaz odnosa ulaganja u dugotrajnu imovinu i prihoda od izvoza u periodu 2006-2015. godine tristo najvećih hrvatskih izvoznih poduzeća. Dodatno, ovim radom se ispituje utječu li ulaganja na jednak način na poduzeća koja ostvaruju većinu svojih prihoda od izvoza i na poduzeća koja ostvaruju prihod na domaćem i inozemnom tržištu, odnosno jesu li ulaganja u dugotrajnu imovinu korelirana s izvoznom orijentacijom poduzeća.

Rad se sastoji od pet dijelova. Nakon uvodnog dijela, drugi dio objašnjava povezanost ulaganja i međunarodne konkurentnosti poduzeća. Treći dio daje pregled industrijske strukture tristo najvećih hrvatskih izvoznika te odnos između ulaganja u dugotrajnu imovinu i prihode od izvoza koji služe kao pokazatelj konkurentnosti. Četvrti dio prikazuje međuodnos ulaganja u dugotrajnu materijalnu imovinu i prihoda od izvoza na primjeru dva hrvatska poduzeća: Plive d.o.o. i Boxmarka d.o.o. dok se petim dijelom zaključuje rad, objašnjavaju ograničenja istraživanja i daju preporuke za buduća istraživanja.

\section{Ulaganja poduzeća u svrhu poboljšanja međunarodne konkurentnosti}

Povećanje bruto domaćeg proizvoda i vanjska trgovina međusobno su povezani. Izvoz djeluje stimulativno na nacionalnu ekonomiju, a posebice na njenu razinu konkurentnosti. Primjerice, Michalopoulos i Jay (1973.) su procijenili kako postotno povećanje prihoda od izvoza rezultira povećanjem bruto društvenog proizvoda za 0,58 
$\%$ do $0,77 \%$. Pregled održivosti vanjskotrgovinske razmjene tri bivše zemlje Jugoslavije, Hrvatske, Slovenije i Srbije, pokazao je kako postoji održiva vanjskotrgovinska razmjena s determinističkim trendom prema ravnoteži (Bošnjak, 2021.). Štoviše, cjenovna i dohodovna elastičnost potražnje za hrvatskim izvoznim proizvodima je potvrđena (Bošnjak i suradnici, 2020.), kao i dohodovna elastičnost potražnja za uvoznim proizvodima (Bošnjak i suradnici, 2019.), no uzrok joj je zaostajanje u tehnološkoj složenosti proizvoda (Buturac, 2019.). Kako izvoz pomaže koncentrirati ulaganja u učinkovitije sektore gospodarstva, potiče asimilaciju novih tehnologija i menadžerskih vještina, povećavajući produktivnost, ekonomija razmjera i smanjujući troškove (Buturac i Vizek, 2015.). Stoga, izvoz i ulaganja su međusobno povezani kada doprinose porastu kapitalnih ulaganja i povećanju učinkovitosti proizvodnih činitelja i napretku tehnologije (Škuflić i Ladavac, 2001.).

Rast izvoza pojedine ekonomije ovisi o postojanju proizvodnih kapaciteta i inozemne potražnje (Šokčević, 2008.). Dakle, potrebno je poboljšati učinkovitost putem ulaganja u proizvodne kapacitete i istraživanje tržišta. Ulaganja omogućavaju poduzećima izlazak na strana tržišta, ili omogućavaju povećanje tržišnog udjela na tržištima na kojima poduzeća već djeluju (Li i Yang, 2015.). lako se u ovom radu ne pravi razlika između stranih i domaćih ulaganja, ukratko se osvrće na važnost stranih ulaganja koji mogu utjecati na promjenu komparativnih prednosti i specijalizaciju zemlje jer (ne)uzrokuju održiv gospodarski rast, već utječu na domaću potražnju (Lovrinčević i suradnici, 2004.).Dostatno je naglasiti da geografska i ekonomska veličina zemlje ukazuje na ovisnost o međunarodnoj vanjskotrgovinskoj razmjeni. Kod „manjih“ ekonomija, među kojima je i Hrvatska, ovisnost o vanjskotrgovinskoj razmjeni je značajnija nego kod „velikih" ekonomija (Šokčević, 2008.). Također, važna je i ekonomska održivost vanjskotrgovinskih tokova (Skoko i Zvonko, 2018.).

\section{Odnos ulaganja i izvoza u najvećim hrvatskim izvoznim poduzećima}

\subsection{Metodologija}

Ovaj rad temelji se na analizi financijskih izvještaja 300 najvećih izvoznih poduzeća u Republici Hrvatskoj u periodu od 2006. do 2015. godine, prema kriteriju veličine prihoda od izvoza. Podaci su dobiveni za tristo najvećih izvoznih poduzeća, no zbog nedostatka podataka za 14 poduzeća, njih se nije analiziralo, te analiza odražava 286 poduzeća. Podaci su dobiveni iz Amadeus baze podataka u 2016. godini, dok su za analizu podataka korištene metode deskriptivne i inferencijalne statistike.

Osim podataka o prihodu od izvoza, promatrana je vrijednost dugotrajne imovine istih poduzeća. Vrijednosti dugotrajne imovine prikazane su u knjigovodstvenom iznosu, amortizirane. Analizirala se promjena neto dugotrajne imovine.
Bašić, M., Ferko, M., Sopta Corić, M.

Ulaganja i izvoz u kontekstu konkurentnosti hrvatskih poduzeća

Tablica 1. Izvozna poduzeća grupirana po industrijama

\begin{tabular}{|l|c|}
\hline \multicolumn{1}{|c|}{ Industrija } & Broj poduzeća \\
\hline Prerađivačka industrija & 156 \\
\hline Veleprodaja i maloprodaja, popravak motornih vozila i motora & 36 \\
\hline Transport i skladištenje & 25 \\
\hline Turizam & 18 \\
\hline Opskrba električnom energijom, plinom, parom i zrakom & 10 \\
\hline Administrativne i ostale usluge podrške & 9 \\
\hline Poljoprivreda, šumarstvo i ribolov & 7 \\
\hline Informacije i komunikacije (IT) & 7 \\
\hline Profesionalne, znanstvene i tehničke aktivnosti & 6 \\
\hline Opskrba vodom i upravljanje otpadom & 5 \\
\hline Građevina & 3 \\
\hline Rudarstvo i vađenje & 2 \\
\hline Ostale uslužne djelatnosti & 2 \\
\hline
\end{tabular}

Izvor: obrada autora prema Amadeus bazi podataka (20.04.2016.). 
Bašić, M., Ferko, M., Sopta Corić, M.

Ulaganja i izvoz u kontekstu konkurentnosti hrvatskih poduzeća

Grafikon 1. Promjene u dugotrajnoj imovini poduzeća po djelatnostima



Izvor: obrada autora prema Amadeus bazi podataka (20.04.2016.).

\subsection{Ulaganja i prihod od izvoza u najvećim hrvatskim izvoznim poduzećima}

Tablica 1. prikazuje izvozna poduzeća grupirana prema industriji u kojoj ostvaruju većinu svoje gospodarske djelatnosti.

Najviše izvoznih poduzeća nalazi se u prerađivačkoj industriji (55 \% ukupnog broja promatranih poduzeća), nakon čega slijede veleprodaja i maloprodaja (36), popravak motornih vozila i motora (36), transport i skladištenje (25).

Nadalje, najviše poduzeća nalazi se u djelatnostima trgovine na veliko, nakon kojeg slijede proizvodnja proizvoda od metala, smještaja, proizvodnje prehrambenih proizvoda.

\subsection{Ulaganja u najvećim hrvatskim izvoznim poduzećima}

Ulaganje u dugotrajnu imovinu uključuje stjecanje i kapitalno poboljšanje dugotrajne imovine: zemljišta, zgrade i građevine, strojeve i opremu te ostala materijalna dugotrajna sredstva. Nematerijalna imovina sastoji se od koncesija, patenata, licenci, robnih i uslužnih marki, softvera, goodwill-a, predujmova za nabavu materijalne imovine te ostale nematerijalna imovina.

Promjene dugotrajne imovine u periodu od deset godina po djelatnostima izražene su u apsolutnim vrijednostima (Grafikon 1.).

Ulaganje u dugotrajnu imovinu prikazano je pozitivnom promjenom dugotrajne imovine. Dodatno, može pokazivati i rast novostečene imovine u odnosu na akumuliranu amortizaciju. Nedostatak ulaganja ili rast akumulirane amortizacije u odnosu na novostečenu imovinu, vidljiv je iz negativne promjene dugotrajne imovine. Vrijednost imovine smanjuje se amortizacijom u slučaju nepostojanja ulaganja. Grafikon 1. prikazuje promjene u dugotrajnoj imovini poduzeća, grupirane po djelatnostima, te godinama. Tamnije označene promjene signaliziraju ranije godine promjene, dok svijetlije boje označavaju recentnije podatke. Akumulirane vrijednosti najvećih promjena u dugotrajnoj imovini poduzeća za period 2006.-2015. godine (samo je par poduzeća s vrijednostima u 2004.i 2005. godini) pokazuju kako najveće promjene, odnosno ulaganja u dugotrajnu imovinu poduzeća imaju djelatnosti: poljoprivrede, proizvodnje prehrambenih proizvoda, trgovine na malo, skladištenja, proizvodnje strojne opreme, proizvodnje farmaceutskih proizvoda, prerade drva, te prikupljanja, obrade i zbrinjavanja otpada.

Najveće negativne promjene, odnosno one u kojima dominira amortizacija vrijednosti, uključuju djelatnosti: proizvodnje duhanskih proizvoda i proizvodnje papira i proizvoda od papira. Trgovina 
Grafikon 2. Najvećih 15 poduzeća po veličini kretanja materijalne imovine



Izvor: obrada autora prema Amadeus bazi podataka (20.04.2016.).

na veliko pokazuje pomak od veće vrijednosti amortizacije ka ulaganjima u kasnijim periodima. Proizvodnja ostalih nemetalnih mineralnih proizvoda i vodeni prijevoz imaju podjednak promjenjiv i dinamičan obrazac ulaganja u različitim godinama.

Petnaest poduzeća s najvećim promjenama dugotrajne imovine u periodu od 2006. do 2015. prikazana su Grafikonom 2.

Najveću promjenu dugotrajne materijalne imovine od 2006. do 2015. godine kontinuirano ostvaruje: (1) Atlantic grupa d.d., a slijede je: (2) Maistra d.d., (3) Jadranka hoteli d.o.o., (4) Plava laguna d.d., (5) Janaf d.d., te (6) Punta skala d.o.o. (Grafikon 2.). Primjećuje se izrazita dinamičnost promjene dugotrajne materijalne imovine kod poduzeća $H Z ̌$

Grafikon 3. Najvećih 10 poduzeća s najvećom ukupnom imovinom po zaposlenom

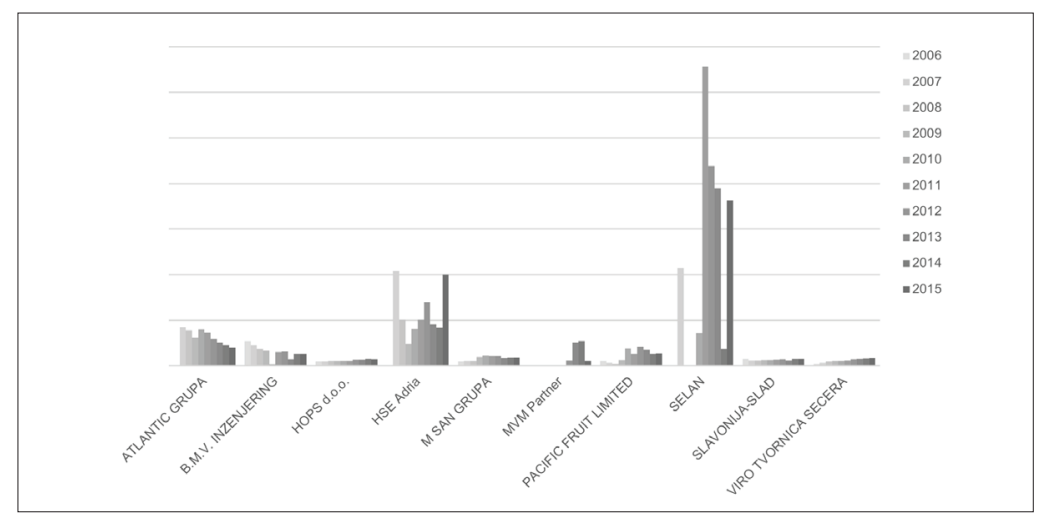

Izvor: obrada autora prema Amadeus bazi podataka (20.04.2016.). 
Bašić, M., Ferko, M., Sopta Corić, M.

Ulaganja i izvoz u kontekstu konkurentnosti hrvatskih poduzeća

Grafikon 4. Najvećih 10 poduzeća s najvećim obrtnim kapitalom po zaposlenom

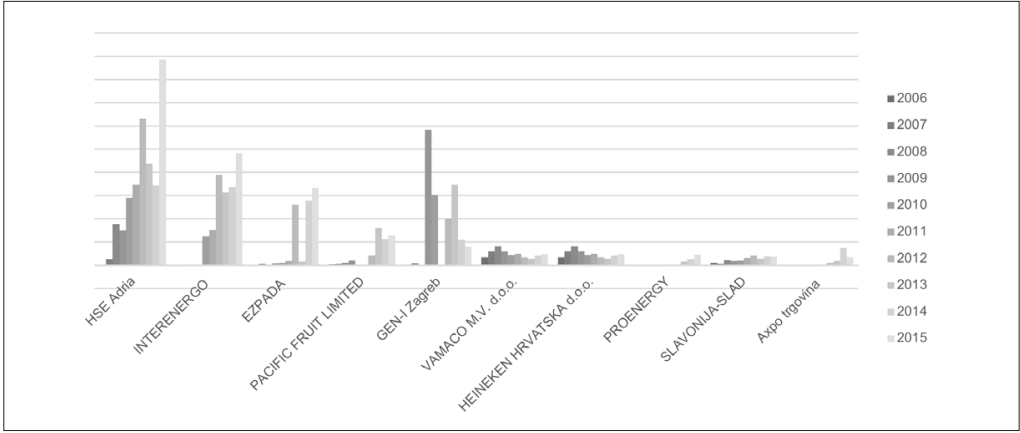

Izvor: obrada autora prema Amadeus bazi podataka (20.04.2016.)..

Cargo d.o.o. i Cemex Hrvatska d.d., dok poduzeća TDR d.o.o., DS Smith Belišće Croatia d.0.0. i Našicecement d.d. bilježe kontinuirano smanjenje vrijednosti materijalne imovine.

Promatrajući ukupnu imovinu po zaposlenom ističu se poduzeća: Atlantic grupa d.d., B.M.V. inženjering d.o.o., HOPS d.0.0., HSE Adria d.o.o., M SAN GRUPA d.0.0., MVM Partner d.0.0.,Pacific Fruit Limited d.0.0., Selan d.0.0., Slavonija-Slad d.0.0. i Viro Tvornica Šećera d.d. (Grafikon 3.). Od navedenih poduzeća najveću ukupnu imovinu po zaposlenom bilježi poduzeće Selan d.o.0., a slijede ga HSE Adria d.o.o.i Atlantic grupa d.d.
Kako bi se promotrila likvidnost poduzeća, Grafikon 4. prikazuje poduzeća s najvećim obrtnim kapitalom po zaposlenom. Obrtni kapital je razlika između kratkotrajne imovine i kratkoročnih obveza i potreban je da bi se premostio jaz između vremena proizvodnje proizvoda ili usluge i prihodovanja od prodaje istih proizvoda ili usluga.

Posljedično, Grafikon 4. daje uvid u poduzeća s najvećim obrtnim kapitalom po zaposlenom, a koje imaju: (1) HSE Adria d.o.o., (2) Interenergo d.o.o. i (3) Ezpada d.o.o.

Grafikon 5. Najvećih 15 djelatnosti po veličini prihoda od izvoza

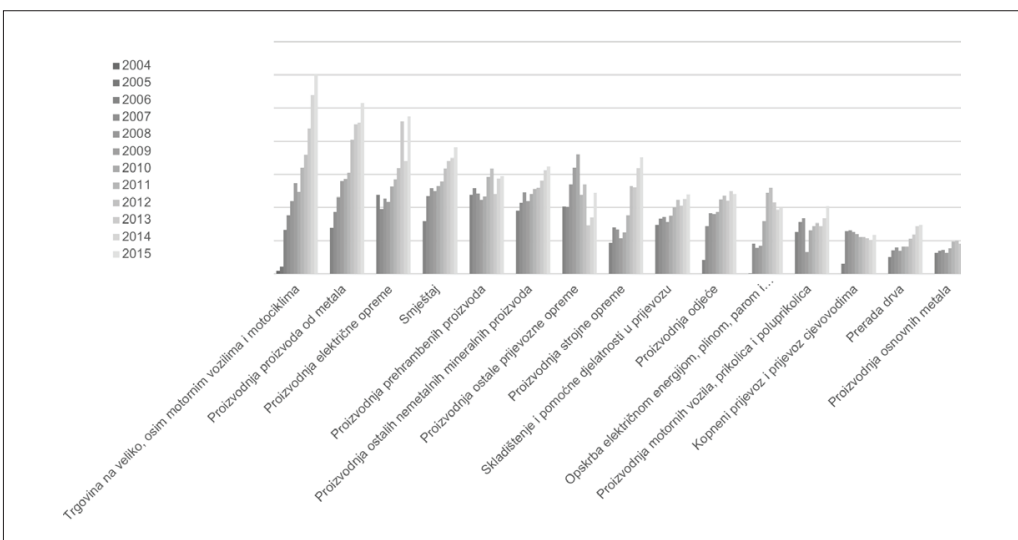

Izvor: obrada autora prema Amadeus bazi podataka (20.04.2016.). 
Tablica 2. Dvadeset poduzeća s ostvarenim najvišim prihodima od izvoza u 2015. godini

\begin{tabular}{|c|c|c|}
\hline Redni broj & Poduzeće & $\begin{array}{l}\text { Prihodi od prodaje } \\
\text { (tisuće EUR) }\end{array}$ \\
\hline 1. & AD PLASTIK d.d. & 97.968 \\
\hline 2. & Harburg Freudenberger Belišće d.o.o. & 97.839 \\
\hline 3. & Hrvatska kontrola zračne plovidbe d.o.o. & 89.019 \\
\hline 4. & GEN-I Hrvatska d.o.o. & 85.389 \\
\hline 5. & Končar - Energetski transformatori d.o.o. & 84.716 \\
\hline 6. & KONČAR - Distributivni i specijalni transformatori d.d. & 84.113 \\
\hline 7. & Maistra d.d. & 80.929 \\
\hline 8. & HS Produkt d.o.o. & 77.397 \\
\hline 9. & Vetropack Straža d.d. & 77.384 \\
\hline 10. & YTRES d.0.0. & 76.221 \\
\hline 11. & ULANIK Brodogradilište d.d. & 76.094 \\
\hline 12. & Ameropa Žitni Terminal d.o.o. & 75.540 \\
\hline 13. & Đuro Đaković termoenergetska postrojenja d.o.o. & 74.266 \\
\hline 14. & OLIMPIAS TEKSTIL d.o.o. & 73.930 \\
\hline 15. & HSE Adria d.o.o. & 69.478 \\
\hline 16. & 3. maj Brodogradilište d.d. & 68.539 \\
\hline 17. & Brodogradilište Viktor Lenac d.d. & 57.461 \\
\hline 18. & P.P.C.BUZET d. 0.0 . & 66.308 \\
\hline 19. & CEMEX Hrvatska d.d. & 65.060 \\
\hline 20. & Bilfinger Đuro Đaković Montaža d.o.o. & 63.126 \\
\hline
\end{tabular}

Izvor: obrada autora prema Amadeus bazi podataka (20.04.2016.).

\subsection{Prihodi od izvoza u najvećim hrvatskim izvoznim poduzećima}

Nakon analiziranih obilježja promjene dugotrajne imovine, prikazani su prihoda od izvoza poduzeća. Poduzeća su također grupirana po djelatnostima.
Grafikon 5. prikazuje prihode od izvoza za 15 djelatnosti s najvećim ostvarenim prihodima od izvoza od 2006. do 2015. godine (samo je nekoliko poduzeća s podacima za 2004. i 2005. godinu koja su stoga uvrštena u prikaz).

Tablica 3. Postotna godišnja promjena prihoda od izvoza dvadeset poduzeća s ostvarenim najvišim prihodima od izvoza u 2015.godini

\begin{tabular}{|c|c|c|}
\hline Redni broj & Poduzeće & $\begin{array}{c}\text { Promjena veličine prihoda od } \\
\text { izvoza (\%) }\end{array}$ \\
\hline 1. & AD PLASTIK d.d. & $27-2$ \\
\hline 2. & Harburg Freudenberger Belišće d.o.o. & 47 \\
\hline 3. & Hrvatska kontrola zračne plovidbe d.o.o. & 6 \\
\hline 4. & GEN-I Hrvatska d.o.o. & 57 \\
\hline 5. & Končar - Energetski transformatori d.o.o. & \\
\hline 6. & KONČAR - Distributivni i specijalni transformatori d.d. & 14 \\
\hline 7. & Maistra d.d. & 14 \\
\hline 8. & HS Produkt d.o.o. & 11 \\
\hline 9. & Vetropack Straža d.d. & 1 \\
\hline 10. & YTRES d.0.0. & 1 \\
\hline 11. & ULANIK Brodogradilište d.d. & 16 \\
\hline 12. & Ameropa Žitni Terminal d.o.o. & 32 \\
\hline 13. & Đuro Đaković termoenergetska postrojenja d.o.o. & 22 \\
\hline 14. & OLIMPIAS TEKSTIL d.o.o. & -20 \\
\hline 15. & HSE Adria d.o.o. & 14 \\
\hline 16. & 3. Maj Brodogradilište d.d. & 61 \\
\hline 17. & Brodogradilište Viktor Lenac d.d. & 62 \\
\hline 18. & P.P.C.BUZET d. 0.0. & 6 \\
\hline 19. & CEMEX Hrvatska d.d. & 7 \\
\hline 20. & Bilfinger Đuro Đaković Montaža d.o.o. & 36 \\
\hline
\end{tabular}

Izvor: obrada autora prema Amadeus bazi podataka (20.04.2016.). 
Bašić, M., Ferko, M., Sopta Corić, M.

Ulaganja i izvoz u kontekstu konkurentnosti hrvatskih poduzeća

Tablica 4. Pregled najvećih promjena prihoda od izvoza po poduzećima u 2015. godini, grupiranih po djelatnostima

\begin{tabular}{|c|c|}
\hline Kopneni prijevoz i prijevoz cjevovodima & \begin{tabular}{c} 
Poduzeće \\
\hline Opskrba električnom energijom, plinom, parom i klimatizacijom
\end{tabular} \\
\hline Proizvodnja električne opreme & Janaf d.d. \\
\hline Proizvodnja motornih vozila, prikolica i poluprikolica & SOLVIS d.o.o. \\
\hline Proizvodnja osnovnih farmaceutskih proizvoda & Ziegler d.o.o. \\
\hline Proizvodnja ostale prijevozne opreme & Hospira Zagreb d.o.o \\
\hline Trgovina na malo, osim motornim vozilima i motociklima & 3. Maj Brodogradilište d.d. \\
& Brodogradilište Viktor Lenac d.d. \\
\hline Trgovina na veliko, osim motornim vozilima i motociklima & HRVATSKA BRODOGRADNJA TROGIR d.o.o.
\end{tabular}

Izvor: obrada autora prema Amadeus bazi podataka (20.04.2016.).

Najveće prihode od izvoza u zadnjoj promatranoj godini (2015. godini) ostvaruje trgovina na veliko, nakon čega slijedi proizvodnja proizvoda od metala, proizvodnja električne opreme, smještaja, prehrambenih proizvoda, te proizvodnja ostalih nemetalnih mineralnih proizvoda (Grafikon 5.). Relativno stabilne prihode od izvoza ostvaruju djelatnosti proizvodnje prehrambenih proizvoda, proizvodnje ostalih nemetalnih mineralnih proizvoda, skladištenja i pomoćnih djelatnosti u prijevozu, te kopnenog prijevoza i prijevoza cjevovodima.

Tablica 2. prikazuje dvadeset poduzeća s najvećim ostvarenim prihodima od izvoza u 2015. godini.

2015. godine najveće prihode od izvoza ostvarila su poduzeća: AD Plastik d.d., Harburg-

Grafikon 6. Pregled najvećih promjena prihoda od izvoza po poduzećima u 2015. godini

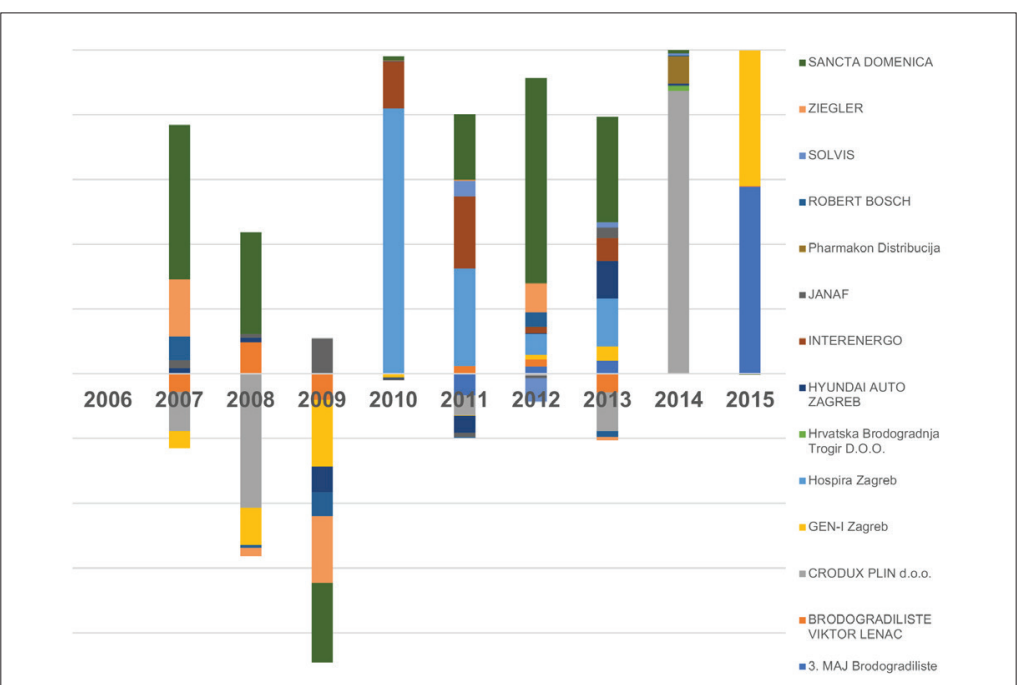

Izvor: obrada autora prema Amadeus bazi podataka (20.04.2016.). 
Freudenberger Belišće d.o.o. te Hrvatska kontrola zračne plovidbe d.o.o. (Tablica 2.). Primjetan je kontinuiran rast izvoznih prihoda svakog poduzeća, što upućuje na rast izvozne orijentacije početkom internacionalizacije poduzeća.

Ukoliko se promatra godišnja promjena prihoda od izvoza za ista poduzeća, primjećuje se da najveći rast izvoznih prihoda u 2015. godini je ostvaren od poduzeća: Brodogradilište Viktor Lenac d.d. (61 \%), 3. Maj Brodogradilište d.d. (61 \%), GEN-I Zagreb d.0.0. (57 \%), Harburg Freudenberger Belišće d.o.o. (47\%), Bilfinger Đuro Đaković Montaža d.o.o.(36\%), Ameropa Žitni Terminal d.o.o. (32 \%), te AD Plastik d.d. (27 \%) (Tablica 3.). Većina postotnih promjena prihoda od izvoza ukazuje na nestabilnosti i velike varijacije u istima, što potvrđuje tezu o dinamičnoj međunarodnoj poslovnoj okolini, koja sa sobom doprinosi nesigurnosti prodaje proizvoda.

Tablica 4. daje detaljan uvid u promjene od prihoda od izvoza u 2015. godini za poduzeća u različitim djelatnostima, dok Grafikon 6. prikazuje poduzeća s najznačajnijom relativnom promjenom prihoda od izvoza u 2015. godini.

Najveću pozitivnu promjenu prihoda od izvoza u 2007. i 2008. godini imalo je poduzeće Sancta Domenica d.0.0. (293 \% i 76 \%), a negativnu Crodux Plin d.0.0.(-74 \% i -100 \%).U 2009. godini primjetno je prelijevanje globalne financijske krize na prihode od izvoza, pri čemu se najveća negativna promjena odnosi upravo na poduzeće Sancta Domenica d.o.o. (-47 \%), te poduzeća GEN-I Hrvatska d.0.o. i Ziegler d.o.o. (svako od ova dva poduzeća je imalo smanjen prihod od $40 \%$ ), dok je najveću pozitivnu promjenu imalo poduzeće Janaf d.d. (21 \%). 2010. i 2011. godine Hospira Zagreb d.o.o i Interenergo d.o.o. imaju najznačajniji rast prihoda od izvoza, a najveće smanjenje bilježe Crodux Plin d.o.o. i Hyundai Hrvatska d.o.o.. Godine 2012. in slijedi Sancta Domenica d.o.o., dok najveće smanjenje bilježi Solvis d.o.o. Crodux Plin d.o.o. bilježi pad i 2013. godine, dok 2014. doživljava veliki porast prihoda od izvoza. Godine 2015. najveći rast zabilježili su 3. Maj Brodogradilište d.d. i GEN-I Hrvatska d.o.o. (Grafikon 6.).

\section{Primjeri ulaganja u dugotrajnu materijalnu imovinu i izvozna uspješnost poduzeća: usporedba Plive d.o.o. i Boxmarka d.0.0.}

Ovaj rad težio je povezati i promjenu dugotrajne materijalne imovine, odnosno ulaganja u dugotrajnu materijalnu imovinu, i promjenu prihoda od izvoza. U tu svrhu dan je primjer slučaja dva poduzeća: Plive d.o.o. (u nastavku: Pliva) i Boxmarka d.o.o.(u nastavku: Boxmark). Pliva je poduzeće u farmaceutskoj industriji koje pokazuje niži stupanj izvozne orijentacije od poduzeća Boxmark čija je primarna djelatnost proizvodnja i obrada kože i tekstila. Stupanj izvozne orijentacije računa se kao udio prihoda od izvoza u ukupnim prihodima poduzeća. Štoviše, farmaceutska industrija u Republici Hrvatskoj je specifična industrija jer u Republici Hrvatskoj djeluju njene 23 međunarodne podružnice, čiji je stupanj autonomije u donošenju odluka ograničen (Podrug i suradnici, 2018.).U obzir je uzet stupanj niže izvozne orijentacije Plive, te ograničen stupanj autonomije u donošenju odluka, a koji ovisi o matici poduzeća, dok je poduzeće Boxmark u vlasništvu Boxmark Leather Holding $\mathrm{GmbH}$ iz Austrije.

Tablica 5. Pregled prihoda od izvoza i stupnja izvozne orijentiranosti poduzeća Pliva d.o.o. i Boxmark d.o.o. 2006-2015.

\begin{tabular}{|c|c|c|c|c|}
\hline \multirow{2}{*}{ Godina } & \multicolumn{2}{|c|}{ Prihodi od izvoza (tisuće EUR) } & \multicolumn{2}{|c|}{ Udio izvoznih prihoda u poslovnim prihodima (\%) } \\
\hline & Pliva d.o.o. & Boxmark d.0.0. & Pliva d.0.0. & Boxmark d.o.o. \\
\hline 2006. & 264 & 160 & 67,84 & 98,15 \\
\hline 2007. & 237 & 171 & 68,79 & 97,96 \\
\hline 2008. & 208 & 170 & 52,88 & 99,99 \\
\hline 2009. & 276 & 156 & 72,74 & 99,99 \\
\hline 2010. & 257 & 212 & 70,49 & 99,00 \\
\hline 2011. & 249 & 240 & 71,91 & 98,75 \\
\hline 2012. & 314 & 26 & 75,69 & 96,39 \\
\hline 2013. & 287 & 249 & 71,32 & 99,85 \\
\hline 2014. & 374 & 327 & 78,25 & 99,87 \\
\hline 2015. & 401 & 349 & 79,31 & 99,95 \\
\hline
\end{tabular}

Izvor: obrada autora prema Amadeus bazi podataka (20.04.2016.). 
Bašić, M., Ferko, M., Sopta Corić, M.

Ulaganja i izvoz u kontekstu konkurentnosti hrvatskih poduzeća

Grafikon 7. Odnos relativne promjene dugotrajne imovine i udjela prihoda od izvoza u poslovnim prihodima - Pliva d.o.0.
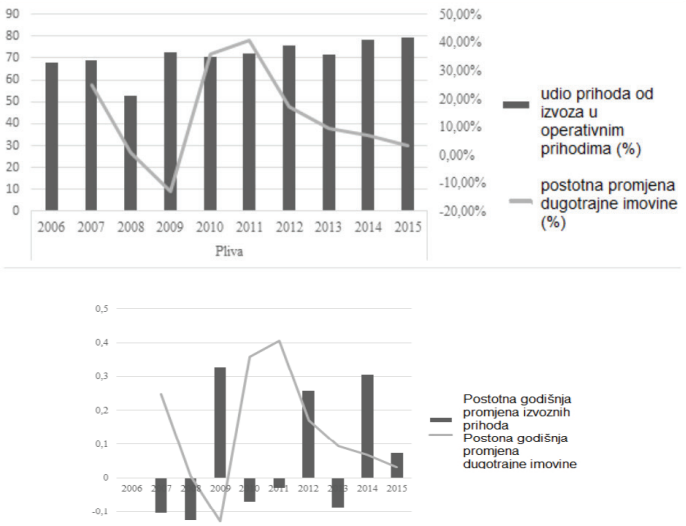

Izvor: obrada autora prema Amadeus bazi podataka (20.04.2016.).

Grafikon 8. Odnos relativne promjene dugotrajne imovine i udjela prihoda od izvoza u poslovnim prihodima - Boxmark d.0.0.
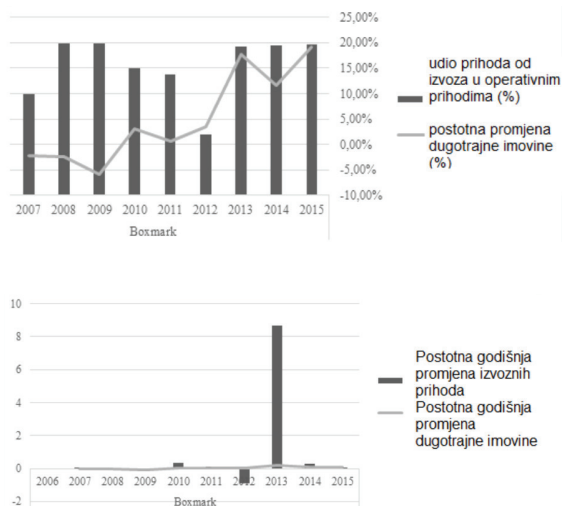

Izvor: obrada autora prema Amadeus bazi podataka (20.04.2016.).

Početna pretpostavka je da poduzeća niže izvozne orijentacije, a istovremeno snažno prisutna na domaćem tržištu te da ulaganjem u dugotrajnu imovinu mogu povećati učinkovitost više nego poduzeća više izvozne orijentacije kod kojih su ulaganja kontinuirana zbog višeg stupnja prilagođavanja inozemnom tržištu.

Tablica 5. uspoređuje u prihode od izvoza i izvoznu orijentiranost Plive i Boxmarka u periodu od 2006. do 2015. godine. 
Nadalje, Grafikoni 7. i 8. ilustriraju međuovisnost relativne promjene dugotrajne imovine i stupnja izvozne orijentiranosti oba poduzeća.

Promatrajući postotne godišnje promjene prihoda od izvoza i dugotrajne imovine primjećuje se povezanost istih za poduzeće Pliva,te nepovezanost za poduzeće Boxmark (Grafikoni 7.i 8.).

\section{Zaključak}

Izvoz i ulaganja su međusobno povezani kada doprinose kapitalnim ulaganjima i rastu učinkovitosti proizvodnih resursa i napretku tehnologije (Škuflić i Ladavac, 2001.).Zbog cjenovne i dohodovne elastičnosti hrvatskog izvoza (Bošnjak i suradnici, 2020.), te predstojeće reintegracije globalnog tržišta (Grgić i Bilas, 2008.), potrebno je ispitati odnos ulaganja i prihoda od izvoza za hrvatska izvozna poduzeća. Ispitivanjem odnosa ulaganja i prihoda od izvoza mogu se dati daljnji prijedlozi o poboljšanju proizvodnih kapaciteta koji bi rezultirali većom tehnološkom složenosti proizvoda i usluga te poboljšali konkurentnost hrvatskih proizvođača (Buturac, 2019.). Dodatno, time bi se i dalo uvid u institucionalne razlike koje postoje između poduzeća koja ulažu, ali su bazirana isključivo na inozemna tržišta i poduzeća koja ulažu u dugotrajnu imovinu, ali balansiraju između domaćeg i inozemnog tržišta. Stoga je ovaj rad dao prikaz odnosa ulaganja u dugotrajnu imovinu i prihoda od izvoza u periodu od 2006-2015. godine tristo najvećih hrvatskih izvoznih poduzeća. Dodatno, ovim radom se ispitalo utječu li ulaganja na jednak način na poduzeća koja ostvaruju većinu svojih prihoda od izvoza i na poduzeća koja ostvaruju prihod na domaćem i inozemnom tržištu. Na temelju analize financijskih izvješća i pokazatelja 300 najvećih izvoznih poduzeća u razdoblju 2006-2015. godine, rezultati deskriptivne i inferencijalne statistike su pokazali kako prema djelatnostima s 32 poduzeća dominira trgovina na veliko po NACE Rev 2., dok prema tipu industrije dominira prerađivačka industrija s 55 \% ukupno promatranih poduzeća. Prema promjeni dugotrajne imovine, odnosno ulaganja u dugotrajnu imovinu, najznačajniji porast dugotrajne imovine primjećuje se u djelatnostima: poljoprivrede, proizvodnje prehrambenih proizvoda, trgovine na malo, skladištenja, proizvodnje strojne opreme, proizvodnje farmaceutskih proizvoda, prerade drva, te prikupljanja, obrade i zbrinjavanja otpada. Najveće negativne promjene, odnosno one u kojima dominira amortizacija vrijednosti, uključuju djelatnosti: proizvodnje duhanskih proizvoda i proizvodnje papira i proizvoda od papira. Trgovina na veliko pokazuje pomak od veće vrijednosti amortizacije ka ulaganjima u kasnijim periodima. Proizvodnja ostalih nemetalnih mineralnih proizvoda $\mathrm{i}$ vodeni prijevoz imaju podjednak promjenjiv i dinamičan obrazac ulaganja u različitim godinama. Povezanost ulaganja u dugotrajnu imovinu i prihoda od izvoza prikazano je primjerima dvaju izvoznih poduzeća: Pliva d.0.o.i Boxmark d.0.0., s različitim izvoznim orijentacijama, iz različitih djelatnosti, ali inozemnih matica poduzeća. Izvozna orijentacija promatra se kao udio izvoznih prihoda u ukupnim prihodima poduzeća. Promatranjem ta dva poduzeća zamijećeno je kako za poduzeće, Pliva d.o.o., koje nije u potpunosti izvozno orijentirano postoji korelacija između promjene prihoda od izvoza i ulaganja u dugotrajnu imovinu. Isto nije zamijećeno za poduzeće koje je u potpunosti izvozno orijentirano, Boxmark d.o.o. Nadalje, zamjećuje se kako su u potpunosti izvozno orijentirana poduzeća koja ostvaruju visoku razinu učinkovitosti, istovremeno prisiljena i kontinuirano ulagati.S druge strane, veća ulaganja su potrebna i poduzećima koja nisu u potpunosti izvozno orijentirana. Kako bi se utvrdio njihov utjecaj na gospodarski rast, potrebno je promatrati ulaganja u dugotrajnu materijalnu i nematerijalnu imovinu s vremenskim odmakom od nekoliko godina. Navedeno predstavlja i ograničenje ovog rada, kao i prijedlog za buduća istraživanja. Dodatno ograničenje ovog rada je dostupnost godišnjih podataka. Podaci su dostupni samo za desetogodišnje razdoblje od 2006. do 2015. godine. lako je ovaj period zanimljiv zbog utjecaja globalne financijske krize 2008. godine i njenog prelijevanja na Republiku Hrvatsku, koju su prvo osjetila hrvatska izvozna poduzeća, ova tematika nije bila u okviru ovog rada. Budući radovi imali bi koristi od promatranja utjecaja prelijevanja smanjenja potražnje na globalnom tržištu na prihode izvoznih poduzeća i time dodatno osnažili i potvrdili utjecaj globalnih financijskih kretanja na realni sektor, posebice realni gospodarski sektor hrvatskih poduzeća. Dodatno, podaci za određena poduzeća u uzorku nedostaju, te je uzorak smanjen za 14 poduzeća od najvećih 300 poduzeća, te iznosi 286 poduzeća. Štoviše, budući radovi trebali bi koristiti naprednije ekonometrijske metode kako bi došli do detaljnijih i empirijski provjerenih zaključaka.
Bašić, M., Ferko, M., Sopta Corić, M.

Ulaganja i izvoz u kontekstu konkurentnosti hrvatskih poduzeća 
Bašić, M., Ferko, M., Sopta Corić, M.

Ulaganja i izvoz u kontekstu konkurentnosti hrvatskih poduzeća

\section{Literatura}

Amadeus baza podataka (2016). Dostupno na: https://amadeus.bvdinfo.com/version-2019919/home. serv?product=AmadeusNeo (20.04.2016.).

Basarac, M., \& Vučković, V. (2011). Analiza izvozne konkurentnosti hrvatske prerađivačke industrije. Ekonomski pregled, 62(12): 729-751.

Bošnjak, M. (2021). Hysteresis in trade flows of ex-Yugoslav countries. Proceedings of FEB Zagreb International Odyssey Conference on Economics and Business, 3(1): 172-181.

Bošnjak, M., Bilas, V., \& Račić, D. (2019). Time-varying parameters of Croatian import demand. Zbornik radova Ekonomskog fakulteta u Rijeci: časopis za ekonomsku teoriju i praksu, 37(2): 853-872. https://doi.org/10.18045/zbefri.2019.2.853

Bošnjak, M., Novak, I., \& Bašić, M. (2020). The demand function for merchandise exports: the case of Croatia. Ekonomska misao i praksa, 29(1): 123-135.

Buturac, G. (2019). Gospodarski rast, konvergencija i članstvo u EU: empirijski dokazi iz Hrvatske. Ekonomski pregled, 70(2): 173-208. https://doi.org/10.32910/ep.70.2.1

Buturac, G., \& Vizek, M. (2015). Izvoz prehrambene industrije i učinci na gospodarstvo: slučaj Hrvatske. Ekonomski pregled, 66(3): 203-230.

Ćudina, A., Lukinić Čardić, G., \& Sušić, G. (2012). Analiza relativnog položaja hrvatskog izvoza na tržištu Europske unije. Ekonomski pregled,63(5-6): 291-321.

Državni zavod za statistiku Republike Hrvatske (2020). Robna razmjena Republike Hrvatske s inozemstvom u 2019., konačni podaci. Državni zavod za statistiku Republike Hrvatske,Zagreb.

Eurostat (2020). Dostupno na: https://ec.europa.eu/eurostat/web/nace-rev2 (20.09.2020.).

Grgić, M., \& Bilas, V. (2008). Međunarodna ekonomija. Lares plus, Zagreb.

Li, Z., \& Yang, D. (2015). The Study on the Influence of Fixed Asset Investment and Foreign Trade to the Economic Growth of Ningbo---Based on VAR Model. Ningbo University, Ningbo, China.

Lacković Vincek, Z., Bošnjak, M., \& Bilas, V. (2019). Primjena metode konstantnih tržišnih udjela na izvoz uslužnoga sektora visoke dodane vrijednosti Republike Hrvatske na tržište Europske unije. Ekonomski pregled, 70(3): 351-379. https://doi.org/10.32910/ep.70.3.1

Landika, M., Jakupović, S., \& Šupuković, V. (2017). Planiranje aktivnosti i optimizacija utroška materijala u funkciji unapređenja kvalitete i razvoja poslovnih sustava. Notitia - časopis za ekonomske, poslovne i društvene teme, 3(1): 91-101.

Lovrinčević,Ž., Buturac, G., \& Marić,Z. (2004).Priljev inozemnog kapitala - utjecaj na domaće investicije i strukturu robne razmjene. Ekonomski pregled, 55(11-12): 894-934.

Michalopoulos, C., \& Jay, K.(1973). Growth of exports and income in the developing world:A neoclassical view. Department of State,Agency for International Development, Bureau for Policy Coordination.

Novak, I. (2020). Comparative analysis of innovation performance of European Union countries. Notitia časopis za ekonomske, poslovne i društvene teme, 6(1): 1-11. https://doi.org/10.32676/n.6.1.1

Podrug, N., Filipović, D., \& Bošnjak, M. (2018). Autonomija međunarodnih podružnica u inovativnoj farmaceutskoj industriji u Republici Hrvatskoj. Notitia - časopis za ekonomske, poslovne i društvene teme, 4(1): $9-23$.

Skoko, B., \& Zovko, P. (2018). Održivost međunarodnih trgovinskih tokova Bosne i Hercegovine. Notitia časopis za ekonomske, poslovne i društvene teme, 4(1): 1-8.

Svjetski ekonomski forum (2019). Izvješće o globalnoj konkurentnosti 2019. Dostupno na: http:// konkurentnost.hr/wpcontent/uploads/2019/10/WEF_TheGlobalCompetitivenessReport2019.pdf (15.07.2020.). 
Škuflić, L., \& Ladavac, J. (2001). Analiza vanjskotrgovinske razmjene Republike Hrvatske po županijama. Ekonomski pregled, 52(7-8): 925-950.

Šokčević, S. (2008). Analiza izvozne sposobnosti hrvatskoga gospodarstva primjenom strategije izvozne ekspanzije. Ekonomski pregled, 59(3-4): 177-194. 
